\title{
Radiotherapy Issues in Elderly Breast Cancer Patients
}

\author{
Ian Kunkler
}

Edinburgh Breast Unit, Western General Hospital, University of Edinburgh, UK

\author{
Keywords \\ Breast cancer · Radiotherapy · Elderly
}

\section{Summary}

Breast cancer in the elderly is a rising health care challenge. Under-treatment is common. While the proportion of older patients receiving adjuvant radiotherapy $(\mathrm{RT})$ is rising, the proportion undergoing breast-conserving surgery without irradiation has also risen. The evidence base for loco-regional treatment is limited, reflecting the historical exclusion of older patients from randomised trials. The 2011 Oxford overview shows that the risk of first recurrence is halved in all age groups by adjuvant RT after breast-conserving surgery, although the absolute benefit in older 'low-risk' patients is small. There is level 1 evidence that a breast boost after breastconserving surgery and whole-breast irradiation reduces local recurrence in older as in younger women, although in the former the absolute reduction is modest. Partial breast irradiation (external beam or intraoperative or postoperative brachytherapy) is potentially an attractive option for older patients, but the evidence base is insufficient to recommend it routinely. Similarly, shortened (hypofractionated) dose fraction schedules may be more convenient for older patients and are supported by level 1 evidence. There remains uncertainty about whether there is a subgroup of older low-risk patients in whom postoperative RT can be omitted after breast-conserving surgery. Biomarkers of 'low risk' are needed to refine the selection of patients for the omission of adjuvant RT. The role of postmastectomy irradiation is well established for 'high-risk' patients but uncertain in the intermediate-risk category of patients with 1-3 involved axillary nodes or node-negative patients with other risk factors where its role is investigational.

\author{
Schlüsselwörter \\ Brustkrebs · Radiotherapie - Ältere Patientinnen
}

\section{Zusammenfassung}

Brustkrebs bei älteren Patientinnen stellt eine wachsende Herausforderung im Gesundheitswesen dar. Nicht ausreichende Behandlung kommt häufig vor. Während der Anteil der älteren Patientinnen, die eine adjuvante Radiotherapie (RT) erhalten, steigt, ist der Anteil derjenigen, die sich einer brusterhaltenden Operation ohne Bestrahlung unterziehen, ebenfalls gestiegen. Die Evidenzlage für eine lokoregionale Behandlung ist begrenzt, was den in der Vergangenheit praktizierten Ausschluss von älteren Patientinnen von randomisierten Studien widerspiegelt. Der Oxford Overview 2011 zeigt, dass sich das Risiko eines ersten Rückfalls in allen Altersgruppen durch die adjuvante RT nach einer brusterhaltenden Operation halbiert hat; der absolute Nutzen der älteren «Niedrigrisiko»-Patientinnen ist jedoch klein. Es liegt Level-1-Evidenz vor, dass eine Boost-Bestrahlung nach einer brusterhaltenden Operation mit anschließender Ganzbrustbestrahlung lokale Rezidive bei älteren genauso wie bei jüngeren Frauen reduziert; bei Ersteren ist die absolute Reduktion jedoch nur mäßig. Eine partielle Bestrahlung der Brust (durch externe Bestrahlung oder intraoperative oder postoperative Brachytherapie) ist möglicherweise eine attraktive Option für ältere Patientinnen. Die Evidenzlage ist für eine routinemäßige Empfehlung jedoch unzureichend. Außerdem können verkürzte (hypofraktionierte) Dosisfraktionsprogramme für ältere Patientinnen angenehmer sein und werden durch Level-1-Evidenz unterstützt. Es bleibt unklar, ob es eine Untergruppe von Niedrigrisiko-Patientinnen gibt, bei denen die postoperative RT nach einer brusterhaltenden Operation unterlassen werden kann. Biomarker, die ein "niedriges Risiko" anzeigen, werden benötigt, um die Selektion von Patientinnen zu verfeinern, denen eine RT erspart werden kann. Die Bedeutung der Bestrahlung nach einer Mastektomie ist bei "Hochrisiko"-Patientinnen erwiesen, sie ist jedoch unklar bei Patientinnen mit mittlerem Risiko, also mit 1-3 involvierten axillären Lymphknoten oder ohne involvierte Lymphknoten, aber mit anderen Risikofaktoren. Hier wird ihre Bedeutung noch erforscht.

\section{KARGER \\ Fax +497614520714 \\ Information@Karger.de}

www.karger.com
(C) 2012 S. Karger GmbH, Freiburg

$1661-3791 / 12 / 0076-0453 \$ 38.00 / 0$

Accessible online at:

www.karger.com/brc
Prof. Ian Kunkler MD

Edinburgh Breast Unit, Western General Hospital

University of Edinburgh

Crewe Road, Edinburgh EH4 2XU, UK

I.Kunkler@ed.ac.uk 


\section{Introduction}

As a consequence of the combination of increasing life expectancy and early breast cancer screening programmes, we are witnessing a rapid rise in both developed and developing countries of breast cancer in the elderly. For example, in the USA over $40 \%$ of patients diagnosed with early breast cancer are aged 65 years or older [1]. In the UK, of the 48,417 cases of breast cancer, $45 \%$ (approximately 21,000) of the patients were aged $\geq 65$ years (www.cruk.org). Definitions of 'elderly' or 'older' patients vary between 65 years and older in North America [2] to 70 years or older in Europe [3].

In this article, the evidence base for loco-regional control from adjuvant radiotherapy (RT) in older patients is reviewed. Particular emphasis is placed on clinical trials.

Breast cancer, which represents $14 \%$ of all cancer deaths, is rising, with approximately $40 \%$ of all new diagnoses in developed countries occurring in women $\geq 65$ years [4]. In the UK, it is estimated that over the next 2 decades, as the older population grows, the breast cancer incidence will rise by $30 \%$ [5]. Despite this rising incidence there is evidence that older patients with breast cancer receive substandard treatment both in relation to surgery, RT and systemic therapy [6-9]. In contrast to larger population-based studies, no difference in receipt of postoperative RT was found by age in a retrospective study from the MD Anderson Hospital [10]. The reason for this disparity is unclear but it could be, as the authors suggest, that at tertiary referral centres older patients are treated more actively or that women who seek referral are more motivated to receive RT. Further investigation is needed to differentiate medically valid reasons for omitting adjuvant RT from failure of health care systems to provide standard care. Identifying the reasons for non-compliance with RT guidelines in the elderly is a priority. In addition, older patients are under-represented in clinical trials.

Elderly patients are less likely to undergo surgery than their younger counterparts. In an international comparison of the surgical management of older patients with early breast cancer in the USA and in 5 European countries aged $\geq 65$ years and diagnosed in 1995-2005, the proportion of patients in whom surgery was omitted increased with age. There were marked variations between countries [11]. In all the countries studied, the use of postoperative RT fell with age. This is a generic issue for older patients with breast and other malignancies $[12,13]$. Older patients are less likely to receive standard treatment in general [13-16]. While the proportion of older patients receiving adjuvant RT for breast cancer is increasing [17], the proportion of elderly patients undergoing breast-conserving surgery without adjuvant RT has also risen [18].

The evidence base for adjuvant RT in older patients is relatively weak, largely due to a dearth of randomised trials. In part, this reflects the exclusion from many trials of women over the age of 70 years. In addition, patients with comorbidi- ties and cognitive impairment are frequently excluded from trials. Selection of older patients for RT has therefore largely been based on extrapolation from results of trials in younger patients and from retrospective subgroup analyses. To address these shortcomings, it has been recommended that there should be fewer exclusion criteria, simpler protocols, more emphasis on the benefits of participation, training of research staff and more home rather than hospital visits [19]. A charter for the rights of older patients in clinical trials has been recommended [20].

\section{Oxford Overview}

The most influential source of data on the overall impact of breast RT on recurrence and survival is the Oxford overview. The 2005 overview showed a causal relationship between loco-regional recurrence and survival. For every 4 local recurrences prevented, 1 breast cancer death was avoided [21]. This is referred to commonly as the ' $4: 1$ ratio'. The latest overview provides data on over 10,000 women in trials of breast-conserving surgery \pm whole-breast RT (WBRT) [22]. There were 1340 patients 70 years or older. In the latest overview [22], the endpoint has changed from first loco-regional recurrence to any first recurrence, whether local or metastatic. Most recurrences, however, remain loco-regional. First recurrence is halved across all age groups. However, the absolute reductions in older patients with low-grade, hormone receptorpositive cancer are very small. The proportional reduction in first recurrence is similar irrespective of age. The risk of any first recurrence at 10 years is reduced by $15.7 \%$ (35\% to $19.3 \%)(95 \%$ confidence interval $(\mathrm{CI}) 13.7-17.7,2 \mathrm{p}=0.00001)$ and the 15-year mortality is reduced by $3.8 \%(25.2 \%$ to $21.4 \%)(95 \%$ CI $1.6-6.0,2 p=0.00005)$. In the $7287 \mathrm{pN} 0$ patients, the equivalent risk reduced with WBRT by $15.4 \%$ from $31 \%$ to $15.6 \%$ (95\% CI $13.2-17.6 \%$ ) with an absolute fall in mortality of $3.3 \%$ from $20.5 \%$ to $17.2 \%$. Most first recurrences were loco-regional (75\%) and were higher in the nonirradiated group. As Giordano [23] has noted, the absolute benefit from RT was much more limited in patients with a lower risk of recurrence.

\section{Does Postoperative RT Impair Quality of Life in Older Patients?}

There is limited data on the impact of postoperative RT on the quality of life in older patients managed by breast-conserving therapy. The PRIME (Postoperative Radiotherapy in Minimum-Risk Elderly) trial provides the only level 1 evidence. 255 patients with T1-T2 tumours up to $5 \mathrm{~cm}$ in axillary node-positive women 65 years or older were randomised to WBRT (40-50 Gy) or no WBRT. Quality of life was the primary outcome measure, with anxiety and depression and cost 
effectiveness as co-primary endpoints. No overall difference in the EuroQoL measurements or in symptoms or functionality domains of the European Organisation for Research on Cancer (EORTC) scales were seen over the first 15 months of the trial [24] or at 5 years [25]. On the basis of the PRIME trial, quality of life should not be a main criterion for selecting older patients for postoperative RT.

\section{Breast Boost Dose after Whole-Breast Irradiation}

There is level 1 evidence that a boost dose to the site of excision after WBRT improves local control in older as in younger patients. However, the absolute benefit is small. This is based on the EORTC boost/no boost trial. It recruited over 5000 patients (including but not exclusive to the elderly) with $\mathrm{T} 1-2$, N0, NI, MO patients after breast-conserving surgery with clear margins. They were randomised to $50 \mathrm{~Gy}$ in 25 fractions over 5 weeks to the whole breast and a boost of $16 \mathrm{~Gy}$ in 8 daily fractions to the tumour bed or to no boost. At 5 years of follow-up [26], a statistically significant benefit of the boost was only seen in women $<50$ years. However, at 10 years of follow-up, for women $\geq 60$ years a statistically significant but small reduction $(3.5 \%)$ in local recurrence was detected from the boost in women $>60$ years [27]. This suggests that all older patients should be considered for a boost after WBRT [28].

\section{Partial Breast Irradiation}

The rationale for focussing the radiation dose on the tumour excision bed (partial breast irradiation (PBI)) is based on the observation that most local recurrences occur within this area. PBI encompasses a range of RT techniques ranging from intraoperative kilovoltage, electron beam or brachytherapy to postoperative external beam and brachytherapy. Intraoperative RT with a single dose of kilovoltage RT or electrons showed equivalent local control to standard fractionated RT over 3-5 weeks. The avoidance of several weeks of external beam would be more convenient to patients and could save significant RT resources. Again, none of these trials are exclusive to older patients. There are 2 current trials of intraoperative RT. In the TARGIT (Targeted Intraoperative Radiotherapy for Breast Cancer) trial of intraoperative kilovoltage RT [29], a single dose of $20 \mathrm{~Gy}$ is prescribed at the surface of the applicator (with $50-\mathrm{kV}$ X-rays). The fall-off in dose is steep (10 Gy within a few millimetres). Kaplan-Meier estimates of ipsilateral breast tumour recurrence in the TARGIT arm at 4 years were $1.20 \%$ and in the external beam arm $0.95 \%$ (95\% CI 0.53-2.71). The ELIOT (The Intraoperative Radiotherapy with Electrons) trial in Milan, Italy, is evaluating intraoperative electrons delivering $21 \mathrm{~Gy}$ as a single fraction with 6-10 MeV electrons [30]. In a North American trial, 38.5 Gy in 10 fractions over 5 days is being studied in a phase III trial with 3-dimensional (3D) conformal postoperative RT [31]. With the rising off-study use of PBI, the American Society of Therapeutic Radiology and Oncology (ASTRO) has published guidelines for the use of accelerated PBI [32]. However, rightly, the guidelines point out that patients offered PBI outside of a clinical study should be made aware of the longer track record of safety and efficacy of WBRT. The GEC-ESTRO (Groupe Européen de Curiethérapie-European Society for Therapeutic Radiology and Oncology) has published equivalent guidelines but without the same rider as ASTRO [33]. Pending more level 1 evidence on PBI, patients should be recruited into prospective trials of PBI.

\section{Hypofractionated RT}

Shortened dose fractionation schedules (hypofractionation) would be beneficial to older patients to reduce tiring daily hospital attendances over 5 weeks for the external beam RT and the social disruption for patients who need to be hospitalised for treatment. Hypofractionation is defined as fractions in excess of the international standard 2 Gy. Two large randomised controlled trials (RCTs) have tested the hypothesis that breast cancer is sensitive to dose per fraction. These trials include but are not exclusive to older patients. Two UK RCTs, which recruited in excess of 4000 patients, have determined tumour and normal tissue responses. In the START A (Standardisation of Breast Radiotherapy A) trial [34], 39 Gy in 13 fractions of 3.2 Gy was compared with 41.6 Gy in 13 fractions of 3 Gy versus a standard of $50 \mathrm{~Gy}$ in 25 fractions over 5 weeks. In the START B trial, a hypofractionated schedule of $40 \mathrm{~Gy}$ in 15 fractions was compared against 50 Gy in 25 fractions [35]. In both trials, patients treated by breast-conserving surgery and mastectomy, appropriate hormonal and/ or chemotherapy were eligible. In node-positive patients, the peripheral lymphatics were also irradiated where appropriate. There were no statistically significant differences in local control or cosmesis in either trial at 5 years. In a Canadian trial, 1234 T1-2 axillary node-negative patients were randomised after breast-conserving surgery (with clear margins) to a hypofractionated regime of $43.5 \mathrm{~Gy}$ in 16 fractions or to a standard of $50 \mathrm{~Gy}$ in 25 fractions in 5 weeks. Follow-up in the Canadian trial was longer than in the START trials and extends to 10 years. It showed no difference in local control or cosmesis [36]. Importantly, there was no difference in cardiac toxicity in the 2 arms of the trial. There is debate on the generalisability of the results of the UK and Canadian trials to routine clinical practice. In the UK, the hypofractionated dose schedule of $40 \mathrm{~Gy}$ in 15 fractions over 3 weeks has been accepted as the standard adjuvant RT regime both after breast-conserving surgery and mastectomy, irrespective of the type of systemic therapy and whether or not the regional lymphatics are irradiated [37]. The ASTRO guidelines on 
hypofractionated RT after breast-conserving surgery are more conservative, restricting hypofractionated $\mathrm{RT}$ to $\mathrm{pN} 0$ patients but excluding patients requiring chemotherapy or peripheral lymphatic irradiation [38]. Hypofractionated adjuvant RT has been more widely adopted in the UK, Europe and Canada than in the USA. The reasons for this discrepancy are unclear but may reflect differences in the organisation of health care systems.

\section{Is there a Subgroup of Patients from Whom Postoperative RT Can Be Omitted after Breast-Conserving Surgery?}

With the rising incidence of older patients with early breast cancer suitable for breast conservation, it is important to establish whether all patients need postoperative RT after breast-conserving surgery. In particular, do pNO patients with smaller, negative, grade 1 or 2 tumours really require postoperative RT if the excision margins are clear? The only randomised trial specifically confined to the elderly is the US Cancer and Leukemia Group B (CALGB) trial [39, 40]. This recruited 636 women with $\mathrm{T} 1$, NO hormone receptor-positive tumours treated with breast-conserving surgery and tamoxifen and randomised them to WBRT or no WBRT. At 5 years of follow-up there was a statistically significant 3\% reduction in local recurrence in the irradiated arm (1\% vs. $4 \%)$. However, the difference was small and an accompanying editorial by Smith and Ross [41] questioned whether such a small difference justified RT. Reflecting the frequency of comorbidity in the elderly, the principal cause of death was not breast cancer but intercurrent disease, particularly cardiac disease. At a median follow-up of 10.5 years [40], it was shown that the difference in local recurrence rate is increasing ( $2 \%$ vs. $9 \%)$ in favour of RT. This reflects the persisting but low cumulative risk of local recurrence up to $10-15$ years. The patterns of deaths from non-cancer causes persisted with only $7 \%$ of deaths due to breast cancer and $36 \%$ due to non-cardiac causes, predominantly vascular. On the basis of the 5-year trial results [39], the National Comprehensive Cancer Network guidelines were amended in 2005, allowing breast irradiation to be omitted in those patients 70 years of age or older with oestrogen receptor-positive, clinically node-negative, TI tumours who receive adjuvant hormonal therapy [12]. However, the guidelines did not specifically recommend RT in this group of women. Nonetheless, the results of the trial seem to have had a minimal impact on the clinical use of RT in the USA in patients who meet the eligibility for the CALGB. Of note, this population $(24,000$ women in 2005$)$ is set to double to around 50,000 by 2030 [1]. Soulos et al. [42] undertook a study using the Surveillance, Epidemiology and End Results (SEER) Medicare database on 12,925 patients with a mean age of 77.7 years who had received postoperative RT. About $79 \%$ of patients received RT before the publication of the
CALGB trial [39] compared to $75 \%$ after the publication. The reasons for the lack of impact of the trial results are unclear. The use of RT did not fall any more in the low-risk subgroup compared to the whole population. One suggestion is that clinicians are less influenced by studies showing the benefit of omitting a treatment than adding one [23]. Alternatively, it might be explained by patient preference. Even if the gain in local control was very modest, it may have seemed worthwhile to patients. We know from studies of adjuvant chemotherapy in the USA that women considered a median acceptable improvement in recurrence risk of $0.5-1.0 \%$ to be worthwhile [43]. Relative advantage was identified as a key factor influencing speed and uptake of innovation [44]. A 3\% reduction in risk of local regional recurrence may have been sufficient for patients to want RT. Giordano [23] poses the question as to whether the innovation of the CALGB trial was superior to what it replaced. Certainly the omission of RT was beneficial in terms of savings in RT costs and avoidance of radiation-induced toxicity. One of the main challenges is that current clinico-pathological factors are inadequate to confidently identify a very-low-risk group in whom postoperative WBRT can be safely omitted. Examples of potentially useful markers are the classification of breast cancer into 5 subtypes with 5 immunohistochemistry (IHC) markers, the BCL-2/Ki67 index and the recent classification of breast cancer into 10 subtypes [45-48]. A prospective cohort of lowrisk, hormone receptor-positive patients treated by breastconserving surgery and adjuvant endocrine therapy alone may be an appropriate design to test the predictive value of different biomarker combinations. A health economic assessment would be required, taking into account savings in RT and patient transport costs as well as costs of treatment of recurrence.

A larger trial, PRIME 2, of over 1300 patients is assessing the impact of the omission of postoperative whole-breast irradiation in women 65 or older with hormone receptor-positive, pN0, T1-2 tumours pathologically $<3 \mathrm{~cm}$, breast-conserving surgery and adjuvant /neoadjuvant endocrine therapy [49]. While not exclusive to the elderly, in the Italian 55-75 trial [50], women aged between 55 and 75 years with T1-2, N0, N1 tumours $(<2.5 \mathrm{~cm})$ were randomised after quadrantectomy with a systemic therapy to whole-breast irradiation (50 Gy in 5 weeks) or no further treatment. Sentinel lymph node biopsy was carried out in N0 patients and axillary node clearance in $\mathrm{N} 1$ patients. This trial involved more extensive local surgery, and higher-risk patients than in the CALGB or PRIME 2 trials were eligible, including pN1 and hormone receptor-negative patients. The cumulative ipsilateral tumour recurrence rate in the Italian trial was $2.5 \%$ in the surgery alone and $0.7 \%$ in the surgery and systemic therapy alone arm. Outside clinical trials within the community setting, data from 8724 patients $\geq 70$ years from the SEER Medicare showed that, in older patients, adjuvant RT reduced the risk of ipsilateral breast tumour recurrence and subsequent 
mastectomy. Patients aged 70-79 years with minimal comorbidity were most likely to gain from RT [51]. Such carefully designed observational studies can provide useful data on the size of treatment effects [52]. However, at present, the international consensus is that there is no subgroup of patients at sufficiently low risk in whom postoperative RT can be systematically omitted [28]. However, given the relatively low baseline risks in this population, it is reasonable to discuss de-escalation of treatment in some elderly patients, particularly those with significant comorbidities [53].

\section{Postmastectomy RT}

There are no elderly-specific trials of postmastectomy RT (PMRT) in elderly patients; so one has to extrapolate from trials that have included older patients. The benefits of locoregional RT on overall survival were established by the Danish Breast Cooperative Group 82c trial [54], which showed a $9 \%$ survival advantage in high-risk postmenopausal women treated by mastectomy and adjuvant tamoxifen. This established PMRT as the standard of care for women with $\geq 4$ or more pathologically involved axillary nodes and T3 tumours. However, the generalisability of the Danish trial to contemporary practice is uncertain. First, the quality of the axillary surgery was inadequate, with too few nodes removed in the axillary clearance. Secondly, the duration of tamoxifen ( 2 years) was shorter than the current standard of 5 years. It is therefore possible that the benefits of PMRT may have been overestimated. It is also notable that the survival benefit of PMRT in the Danish trial only emerged at 5 years. This implies that, for patients with a life expectancy of less than 5 years, for example from comorbidities, PMRT may not be justifiable. For women $>70$ years there is no level 1 data. There are retrospective data implying that the survival benefit of PMRT may extend to women $>70$ years [55]. There is some evidence that 'high-risk' older women may be at higher risk of loco-regional recurrence. A retrospective study com- paring women $\geq 70$ years with those aged 50-69 years showed, in the group with $\geq 4$ or more pathologically involved axillary nodes, that the loco-regional recurrence rate was higher in the older age group (30.8\% vs. $16.8 \%)$ at a median follow-up of 8.3 years [56]. The role of PMRT in 'intermediate-risk' breast cancer (1-3 nodes positive or node negative with other factors such as grade 3 histology or lymphovascular invasion) is controversial, with advocates [57-58] and sceptics [59] about its routine role in this subgroup of patients This research question is being investigated in the international Medical Research Council (MRC)/EORTC SUPREMO (Selective Use of Postoperative Radiotherapy after Mastectomy) trial [60], which has no upper age limit. In its translational substudy, TRANS-SUPREMO, molecular markers of radiation response and resistance are being sought to improve the future selection of patients who are likely to benefit from PMRT more reliably than current clinico-pathological factors.

\section{Conclusions}

There is a limited amount of level 1 evidence on the role of adjuvant RT in the elderly. At present there is no subgroup of older patients in whom postoperative RT can be systematically omitted after breast-conserving surgery. There is robust clinical trial evidence to support the introduction of hypofractionated RT after both breast-conserving surgery and mastectomy for all patients requiring adjuvant postoperative RT. The roles of PBI and PMRT in women at intermediate risk of recurrence are under investigation in clinical trials. Entry of patients into the trials should be strongly encouraged to strengthen the evidence base for this age group.

\section{Disclosure Statement}

The author has no conflicts of interest.

\section{References}

1 Jemal A, Murray T, Ward E, Samuels A, Tiwari RC, Ghafoor A, Feuer EJ, Thun MJ: Cancer statistics, 2005. CA Cancer J Clin 2005;55:10-30.

2 Albrand G, Terret C: Early breast cancer in the elderly: assessment and management considerations. Drugs Aging 2008;25:35-45.

3 Cutuli B, De Lafontan B, Vitali E, Costa L, Aristei C, Marchal C, Quetin P, Fay R: Breast conserving treatment (BCT) for stage I-II breast cancer in elderly women: analysis of 927 cases. Crit Rev Oncol Hematol 2009;71:79-88.

4 Jemal A, Bray F, Center MM, Ferlay J, Ward E, Forman D: Global cancer statistics. CA Cancer J Clin 2011;61:69-90.

5 Thun MJ, DeLancey JO, Center MM, Jemal A, Ward EM: The global burden of cancer: priorities for prevention. Carcinogenesis 2010;31:100-110.
6 Edge SB, Gold K, Berg CD, Meropol NJ, Tsangaris TN, Gray L, Petersen BM Jr, Hwang YT, Mandelblatt JS; Outcomes and Preferences for Treatment in Older Women Nationwide Study Research Team: Patient and provider characteristics that affect the use of axillary dissection in older women with stage I-II breast carcinoma. Cancer 2002;94:2534-2541.

7 Steinfeld AD, Diamond JJ, Hanks GE, Coia LR, Kramer S: Patient age as a factor in radiotherapy. Data from the Patterns of Care study. J Am Geriatr Soc 1989;37:335-338.

8 Kantorowitz DA, Poulter CA, Sischy B, Paterson E, Sobel SH, Rubin P, Dvoretsky PA, Mishalak W, Doane KL: Treatment of breast cancer among elderly women with segmental mastectomy or segmental mastectomy plus postoperative radio- therapy. Int J Radiat Oncol Biol Phys 1988:15:263270.

9 Ballard-Barbash R, Potosky AL, Harlan LC, Nayfield SG, Kessler LG: Factors associated with surgical and radiation therapy for early stage breast cancer in older women. J Natl Cancer Inst 1996;88:716-726.

10 Giordano SH, Hortobagyi GN, Kau SW, Theriault RL, Bondy ML: Breast cancer treatment guidelines in older patients. J Clin Oncol 2005;23:783-791.

11 Kiderlen M, Bastiaannet E, Walsh PM, Keating NL, Schrodi S, Engel J, van de Water W, Ess SM, van Eycken L, Miranda A, de Munck L, van de Velde CJ, de Craen AJ, Liefers GJ: Surgical treatment of early stage breast cancer in elderly: an international comparison. Breast Cancer Res Treat 2012;132:675-682. 
12 National Comprehensive Cancer Network: Clinical Practice Guidelines in Oncology: Breast Version 1,2005. Fort Washington, PA, National Comprehensive Cancer Network, 2005, p BINV2.

13 Samet J, Hunt WC, Key C, Humble CG, Goodwin JS: Choice of cancer therapy varies with age of patient. JAMA 1986;255:3385-3390.

14 Mor V, Masterson-Allen S, Goldberg RJ, Cummings FJ, Glicksman AS, Fretwell MD: Relationship between age at diagnosis and treatments received by cancer patients. J Am Geriatr Soc 1985;33:585-589.

15 Yancik R, Wesley MN, Ries LA, Havlik RJ, Edwards BK, Yates JW: Effect of age and comorbidity in postmenopausal breast cancer patients aged 55 and older. JAMA 2001;285:885-892.

16 O'Connell JB, Maggard MA, Ko CY: Cancer-directed surgery for localized disease: decreased use in the elderly. Ann Surg Oncol 2004;11:962-969.

17 Busch E, Kemeny M, Fremgen A, Osteen RT Winchester DP, Clive RE: Patterns of breast cancer care in the elderly. Cancer 1996;78:101-111.

$18 \mathrm{Du}$ X, Freeman JL, Freeman DH, Syblik DA, Goodwin JS: Temporal and regional variation in the use of breast-conserving surgery and radiotherapy for older women with early-stage breast cancer from 1983 to 1995 . J Gerontol A Biol Sci Med Sci 1999;54:M474-M478.

19 Watts G: Why the exclusion of older people from clinical research must stop. BMJ 2012;344:e3445.

20 PREDICT: Increasing the participation of the elderly in clinical trials. Literature review 20008. www.predicteu.org/Reports/PREDICT_WP1_Report. $p d f$.

21 Early Breast Cancer Trialists' Collaborative Group (EBCTCG): Effects of chemotherapy and hormonal therapy for early breast cancer on recurrence and 15-year survival: an overview of the randomised trials. Lancet 2005;365:1687-1717.

22 Early Breast Cancer Trialists' Collaborative Group (EBCTCG): Effect of radiotherapy after breastconserving surgery on 10-year recurrence and 15year breast cancer death: meta-analysis of individual patient data for 10,801 women in 17 randomised trials. Lancet 2011;378:1707-1716.

23 Giordano SH: Radiotherapy in older women with low-risk breast cancer: Why did practice not change? J Clin Oncol 2012;30:1577-1578.

24 Prescott RJ, Kunkler IH, Williams LJ, King CC, Jack W, van der Pol M, Goh TT, Lindley R, Cairns J: A randomised controlled trial of postoperative radiotherapy following breast-conserving surgery in a minimum-risk older population. The PRIME trial. Health Technol Assess 2007;11:1149, iii-iv.

25 Williams LJ, Kunkler IH, King CC, Jack W, van der Pol M: A randomised controlled trial of post-operative radiotherapy following breastconserving surgery in a minimum-risk population. Quality of life at 5 years in the PRIME trial. Health Technol Assess 2011;15:1-57.

26 Bartelink H, Horiot JC, Poortmans P, Struikmans H, Van den Bogaert W, Barillot I, Fourquet A, Borger J, Jager JJ, Hoogenraad W, Collette L, Pierart M; European Organization for Research and Treatment of Cancer Radiotherapy and Breast Cancer Groups: Recurrence rates after treatment of breast cancer with standard radiotherapy with or without additional radiation. $\mathrm{N}$ Engl J Med 2001;345:1378-1387.

27 Bartelink H, Horiot JC, Poortmans PM, Struikmans H, Van den Bogaert W, Fourquet A, Jager JJ, Hoogenraad WJ, Oei SB, WárlámnRodenhuis CC, Pierart M, Collette L: Impact of a higher radiation dose on local control and survival in breast-conserving therapy of early breast cancer: 10-year results of the randomized boost versus no boost EORTC 22881-10882 trial. J Clin Oncol 2007;25:3259-3265.

28 Biganzoli L, Wildiers H, Oakman C, Marotti L, Loibl S, Kunkler I, Reed M, Ciatto S, Voogd AC, Brain E, Cutuli BM, Terret C, Gosney M, Aapro M, Audisio R: Management of elderly patients with breast cancer: updated recommendations of the International Society of Geriatric Oncology (SIOG) and European Society of Breast Cancer Specialists (EUSOMA). Lancet Oncol 2012;13:e148-e160.

29 Vaidya JS, Joseph DJ, Tobias JS: Targeted intraoperative radiotherapy versus whole breast radiotherapy for breast cancer (TARGIT-A trial): an international, prospective, randomised, non-inferiority phase 3 trial. Lancet 2010;376:91-102.

30 Intra M, Luini A, Gatti G, Ciocca M, Gentilini OD, Viana AA, Chagas EM, Berrettini A, Schuh F, Scarpa D, Orecchia R, Veronesi U: Surgical technique of intraoperative radiation therapy with electrons (ELIOT) in breast cancer: a lesson learned by over 1000 procedures. Surgery 2006;140:467471.

31 Chen PY, Wallace M, Mitchell C, Grills I, Kestin L, Fowler A, Martinez A, Vicini F: Four-year efficacy, cosmesis, and toxicity using three-dimensional conformal external beam radiation therapy to deliver accelerated partial breast irradiation. Int J Radiat Oncol Biol Phys 2010;76:991-997.

32 Smith BD, Arthur DW, Buchholz TA, Haffty BG, Hahn CA, Hardenbergh PH, Julian TB, Marks LB, Todor DA, Vicini FA, Whelan TJ, White J, Wo JY, Harris JR: Accelerated partial breast irradiation consensus statement from the American Society of Radiation Oncology (ASTRO). J Am Coll Surg 2009;209:269-277.

33 Polgár C, Van Limbergen E, Pötter R, Kovács G, Polo A, Lyczek J, Hildebrandt G, Niehoff P, Guinot JL, Guedea F, Johansson B, Ott OJ, Major T, Strnad V; GEC-ESTRO breast cancer working group: Patient selection for accelerated partial-breast irradiation (ABPI) after breast-conserving surgery: recommendations of the Groupe Européen de Curiethérapie-European Society for Therapeutic Radiology and Oncology (GEC-ESTRO) breast cancer working group based on clinical evidence (2009). Radiother Oncol 2010;94:264273.

34 START Trialists' Group, Bentzen SM, Agrawal RK, Aird EG, Barrett JM, Barrett-Lee PJ, Bliss JM, Brown J, Dewar JA, Dobbs HJ, Haviland JS, Hoskin PJ, Hopwood P, Lawton PA, Magee BJ, Mills J, Morgan DA, Owen JR, Simmons S, Sumo G, Sydenham MA, Venables K, Yarnold JR: The UK Standardisation of Breast Radiotherapy (START) Trial A of radiotherapy hypofractionation for treatment of early breast cancer: a randomised trial. Lancet Oncol 2008;9:331-341.

35 START Trialists' Group, Bentzen SM, Agrawal RK, Aird EG, Barrett JM, Barrett-Lee PJ, Bentzen SM, Bliss JM, Brown J, Dewar JA, Dobbs HJ, Haviland JS, Hoskin PJ, Hopwood P, Lawton PA, Magee BJ, Mills J, Morgan DA, Owen JR, Simmons S, Sumo G, Sydenham MA, Venables K, Yarnold JR: The UK Standardisation of Breast Radiotherapy (START) Trial B of radiotherapy hypofractionation for treatment of early breast cancer: a randomised trial. Lancet 2008;371:1098-1107.

36 Whelan TJ, Pignol JP, Levine MN, Julian JA, MacKenzie R, Parpia S, Shelley W, Grimard L, Bogen J, Lukka H, Perera F, Fyles A, Schneider K, Gulavita S, Freeman C: Long-term results of hypofractionated radiation therapy for breast cancer. N Engl J Med 2010;362:513-520.

37 National Institute for Clinical Excellence (NICE) Early and Locally Advanced Breast Cancer: Diagnosis and Treatment. London, NICE, 2009.

38 Smith BD, Bentzen SM, Correa CR, Hahn CA, Hardenbergh PH, Ibbott GS, McCormick B McQueen JR, Pierce LJ, Powell SN, Recht A, Taghian AG, Vicini FA, White JR, Haffty BG: Fractionation for whole breast irradiation: an American Society for Radiation Oncology (ASTRO) evidence-based guideline. Int J Radiat Oncol Biol Phys 2011;81:59-68.

39 Hughes KS, Schnaper LA, Berry D, Cirrincione C, McCormick B, Shank B, Wheeler J, Champion LA, Smith TJ, Smith BL, Shapiro C, Muss HB, Winer E, Hudis C, Wood W, Sugarbaker D, Henderson IC, Norton L; Cancer and Leukemia Group B; Radiation Therapy Oncology Group; Eastern Cooperative Oncology Group: Lumpectomy plus tamoxifen with or without irradiation in women 70 years of age or older with early breast cancer. N Engl J Med 2004:351:971-977.

40 Hughes KS, Schnaper LA, Cirrincione C, Berry DA, McCormick B, Muss HB, Shank B, Hudis C, Winer EP, Smith BL: Lumpectomy plus tamoxifen with or without irradiation in women aged 70 or older with early breast cancer. J Clin Oncol 2010;28(suppl 15):507.

41 Smith IE, Ross GM: Breast radiotherapy after lumpectomy - no longer always necessary. N Eng J Med 2004;351:1021-1023.

42 Soulos PR, Yu JB, Roberts KB, Raldow AC, Herrin J, Long JB, Gross CP: Assessing the impact of a cooperative group trial on breast cancer care in the medicare population. J Clin Oncol 2012;30:1601-1607.

43 Ravdin PM, Siminoff IA, Harvey JA: Survey of breast cancer patients concerning their knowledge and expectations of adjuvant therapy. J Clin Oncol 1998;16:515-521.

44 Rogers EM: Diffusion of Innovations, ed 4. New York, Free Plaza, 1995.

45 Blows FM, Driver KE, Schmidt MK, Broeks A, van Leeuwen FE, Wesseling J, Cheang MC, Gelmon K, Nielsen TO, Blomqvist C, Heikkilä P, Heikkinen T, Nevanlinna H, Akslen LA, Bégin LR, Foulkes WD, Couch FJ, Wang X, Cafourek V, Olson JE, Baglietto L, Giles GG, Severi G, McLean CA, Southey MC, Rakha E, Green AR, Ellis IO, Sherman ME, Lissowska J, Anderson WF, Cox A, Cross SS, Reed MW, Provenzano E, Dawson SJ, Dunning AM, Humphreys M, Easton DF, García-Closas M, Caldas C, Pharoah PD, Huntsman D: Subtyping of breast cancer by immunohistochemistry to investigate a relationship between subtype and short and long term survival: a collaborative analysis of data for 10,159 cases from 12 studies. PLoS Med 2010;7:e1000279.

46 Dawson SJ, Makretsov N, Blows FM, Driver KE, Provenzano E, Le Quesne J, Baglietto L, Severi G, Giles GG, McLean CA, Callagy G, Green AR, Ellis I, Gelmon K, Turashvili G, Leung S, Aparicio S, Huntsman D, Caldas C, Pharoah P: BCL2 in breast cancer: a favourable prognostic marker across molecular subtypes and independent of adjuvant therapy received. Br J Cancer 2010;103:668-675.

47 Ali HR, Dawson SJ, Blows FM, Provenzano E, Leung S, Nielsen T, Pharoah PD, Caldas C: A Ki67/BCL2 index based on immunohistochemistry is highly prognostic in ER-positive breast cancer. J Pathol 2012;226:97-107. 
48 Curtis C, Shah SP, Chin SF, Turashvili G, Rueda OM, Dunning MJ, Speed D, Lynch AG, Samarajiwa S, Yuan Y, Gräf S, Ha G, Haffari G, Bashashati A, Russell R, McKinney S; METABRIC Group, Langerød A, Green A, Provenzano E, Wishart G, Pinder S, Watson P, Markowetz F, Murphy L, Ellis I, Purushotham A, Børresen-Dale AL, Brenton JD, Tavaré S, Caldas C, Aparicio S: The genomic and transcriptomic architecture of 2,000 breast tumours reveals novel subgroups. Nature 2012;486:346-352.

49 Kunkler I: PRIME II breast cancer trial. Clin Oncol 2004;16:447-448.

50 Tinterri C, Gatzemeier W, Zanini V, Regolo L, Pedrazzoli C, Rondini E, Amanti C, Gentile G, Taffurelli M, Fenaroli P, Tondini C, Sacchetto G, Sismondi P, Murgo R, Orlandi M, Cianchetti E, Andreoli C: Conservative surgery with and without radiotherapy in elderly patients with early-stage breast cancer: a prospective randomised multicentre trial. Breast 2009;18:373-377.

51 Smith BD, Gross CP, Smith GL, Galusha DH, Bekelman JE, Haffty BG: Effectiveness of radiation therapy for older women with early breast cancer. J Natl Cancer Inst 2006;98:681-690.

52 Concato J, Shah N, Horwitz RI: Randomized, controlled trials, observational studies, and the hierarchy of research designs. N Engl J Med 2000;342:1887-1892.

53 Beadle BM, Woodward WA, Buchholz TA: The impact of age on outcome in early-stage breast cancer. Semin Radiat Oncol 2011;21:26-34.

54 Overgaard M, Jensen MB, Overgaard J, Hansen PS, Rose C, Andersson M, Kamby C, Kjaer M, Gadeberg CC, Rasmussen BB, Blichert-Toft M, Mouridsen Hat: Postoperative radiotherapy in high-risk postmenopausal breastcancer patients given adjuvant tamoxifen: Danish Breast Cancer Cooperative Group DBCG 82c randomised trial. Lancet 1999;353:1641-1648.

55 Smith BD, Haffty BG, Hurria A, Galusha DH, Gross CP: Postmastectomy radiation and survival in older women with cancer. J Clin Oncol 2006;24:4901-4907.

56 Truong PT, Lee J, Kader HA, Speers CH, Olivotto IA: Locoregional recurrence risks in elderly breast cancer patients treated with mastectomy without adjuvant radiotherapy. Eur J Cancer 2005;41:1267-1277.

57 Poortmans P: Evidence based radiation oncology: breast cancer. Radiother Oncol 2007;84:84-101.

58 Marks LB, Zeng J, Prosnitz LR: One to three versus four or more positive nodes and postmastectomy radiotherapy: time to end the debate. J Clin Oncol 2008; 26:2075-2077.

59 Russell NS, Kunkler IH, van Tienhoven G, Canney PA, Thomas J, Bartlett J, van de Vijver MJ, Belkacemi Y, Yarnold JR, Barrett-Lee PJ: Postmastectomy radiotherapy: Will the selective use of postmastectomy radiotherapy study end the debate? J Clin Oncol 2009;27:996-997.

60 Kunkler IH, Canney P, van Tienhoven G, Russell NS; MRC/EORTC (BIG 2-04) SUPREMO Trial Management Group: Elucidating the role of chest wall irradiation in 'intermediate-risk' breast cancer: the MRC/EORTC SUPREMO trial. Clin Oncol 2008;20:31-34 